\title{
Remedial Method against Moisture Problems - Church of St. Abdon and Sennen in Gemersky Jablonec
}

\author{
Ladislav Ťažký, Anna Sedláková \\ Technical University of Košice \\ Civil Engineering Faculty, Institute of Architectural Engineering \\ e-mail: ladislav.tazky@tuke.sk, anna.sedlakova@tuke.sk
}

\begin{abstract}
Moisture is a major source of damage in historic solid masonry. Rising damp is a well-known phenomenon around the world and occurs when groundwater flows into the base of a construction and is allowed to rise through the pore structure. From practical experience it is known that many factors may play a role regarding permeability problems in masonry. The amount of possible causes of moisture problems in historic masonry underlines the complexity of this phenomenon. Evaporation is an important factor in rising damp. The surface of an affected wall contains moisture that has risen from the ground and this moisture is then subject to evaporation. The factors controlling evaporation include: temperature, humidity, air movement and surface.
\end{abstract}

Key words: rising damp, ventilation of air channel, drainage, historical building, masonry

\section{Introduction}

Nowadays architects use ventilated air channels only for remediation of damp masonry in historical buildings. But in the past they routinely used for new buildings as a protection against moisture. The principle of the system is 4500 year old but it is still functional only the material is different. Ventilated air channel systems are important every time. This is because in historical buildings the use of radical methods are prohibited. At present many ventilated air systems are designed incorrectly and are not functional. The channels are divided according to various aspects such as: location (exterior, interior), method of ventilation (from the exterior, from the interior) and method of airflow (naturally or forced). For the church in Gemerský Jablonec we proposed only the external channel. 


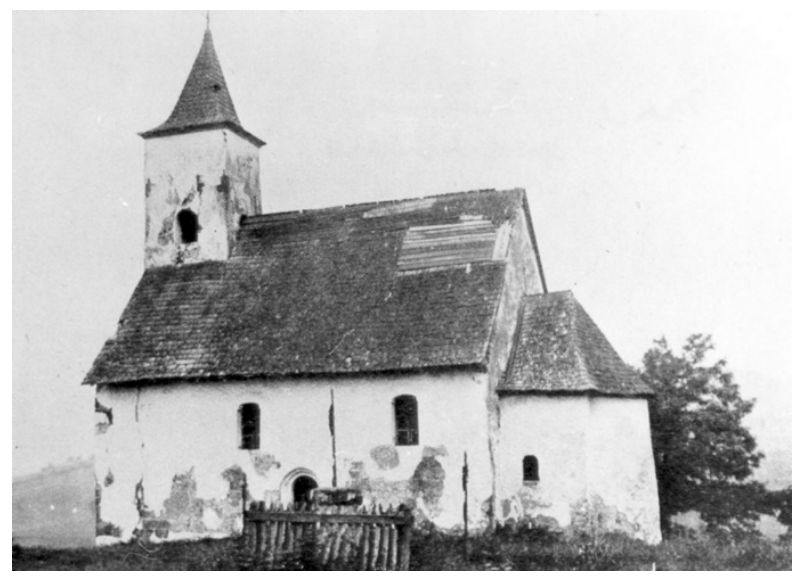

Figure 1: The church in Gemersky Jablonec in year 1932

\section{History of the church}

The church in Gemersky Jablonec is the oldest in the micro region Medves, which is a valuable monument of the Romanesque architecture. In the construction of the church architect used different materials. The foundation is made of brick and above stone blocks are used. The walls were probably plastered. In the $18^{\text {th }}$ century the church was modified. The original Romanesque windows on the south side of the church were walled up and new and larger ones were created instead. The new windows are a feature of Baroque architecture. In the $18^{\text {th }}$ century the sacristy was added to the north side. In 1933 the church was renovated (Fig. 1). In 1969 an archeological survey was conducted where archeologists discovered the remains of the fortification walls protecting the building. In 2008 the dehumidification of the walls begun from the outside and during this process another archeological research was conducted which confirmed the origin of the Roman church. In the summer of 2013 (Fig. 2), work began on the dehumidification of masonry which started by removing of the original plaster to the height at around $1500 \mathrm{~mm}$ and replaced by the appropriate remediation plaster.

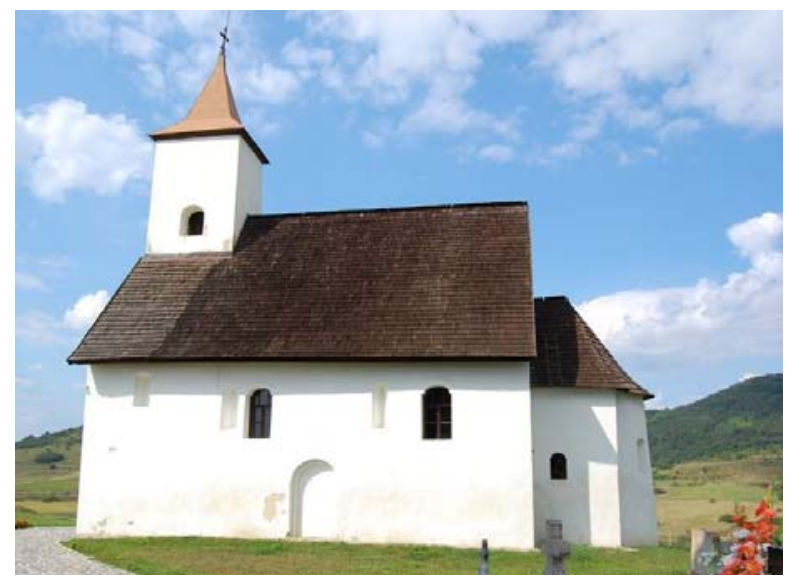

Figure 2: The church in Gemersky Jablonec nowadays 


\subsection{Description of damages}

During the visual survey it was found that the moisture content of the internal masonry pillars reaches up to the height at around $1700-1900 \mathrm{~mm}$. The situation was the worst at the apse of the east side of the church. On the inner surface of the plaster there was visible efflorescence and mildew occurrences especially in the higher parts of the plinth. On the outside of the walls there are still visible lichens, mosses and algae. During the reconstruction of the 80es a gutter walkway was built around the church which only worsened the situation. The biggest problem is the concrete sidewalk on the west side of the church, which compresses the water towards the walls and concentrate at the foundations.

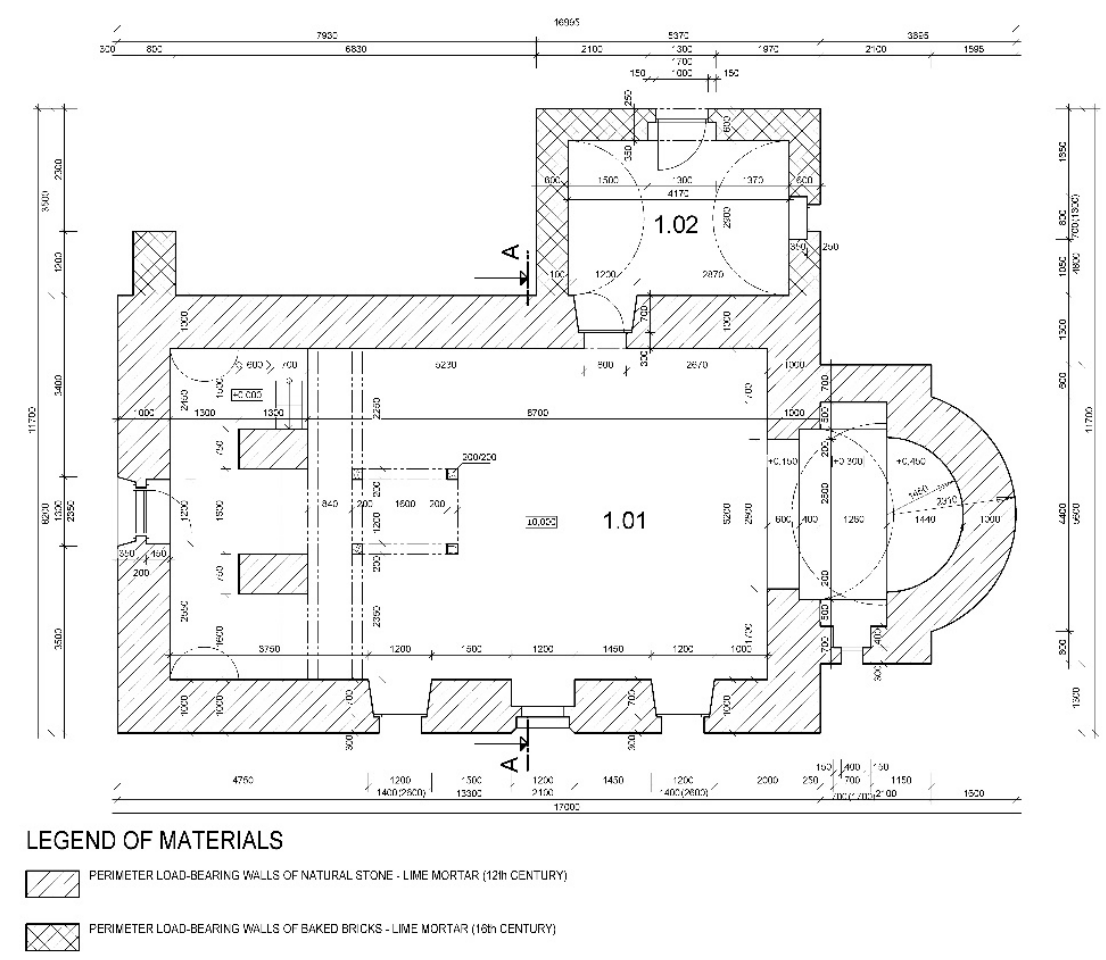

Figure 3: Floor plan of the church

Predicted sources of moisture:

- The increased surrounding terrain, which increase the concentration of the moisture on the outer walls;

- The waterproof PVC covering which was laid in the 80es on the original ceramic tiles;

- The waterproof plinth which is formed of the synthetic color on the walls;

- No roof drainage system. Rain is driven by the wind on the perimeter walls and the water runs down the surface;

- The moisture regime of the church is inappropriate, the worst of all is the unsystematic and almost no ventilation;

- The removed concrete gutter pavement in 2008 which was replaced with a drainage pipe in the gravel embankment, which was only effective for 2 years and thus does not fulfill its function. 


\section{Design of air channel}

The church is a protected cultural monument and a historic value should be particularly sensitive to any remediation done. To improve the technical condition of the church minor structural modification is required [7].

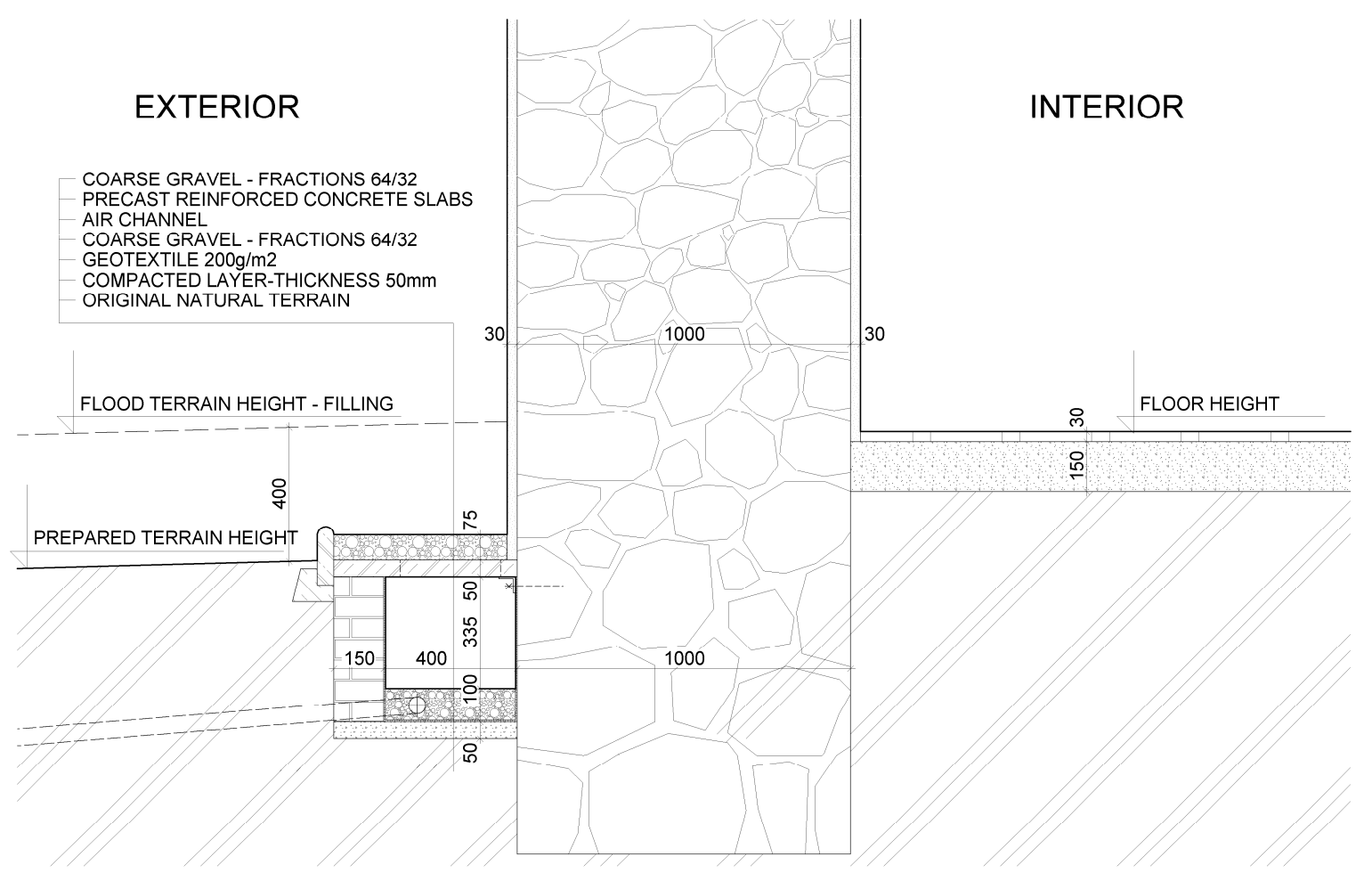

Figure 4: Detail of the foundation with air channel

\subsection{Geometry of air channel}

The drain pipes will be replaced with outdoor air channel. The channel must be masoned of ceramic burned bricks with lime-cement mortar to ensure the natural evaporation of moisture from the soil through the brick masonry. The bottom of the air channel will be filled with gravel; the drain pipe will be placed in this layer to ensure the drainage of water. The next step will be the coverage of the channel with precast concrete panels. These panels are perforated to ensure the natural evaporation from the channel $[4,5,6,7]$.

\subsection{Simulated variants}

We designed the cross-section dimensions of ventilated air channel in 15 variants. The size and values of air pressures and air velocities are shown in the Table 1. The air pressure and air velocity values are from the second simulation. In the second simulation we used the values of air pressure what we obtained from the first simulation. We designed the church and terrain in the first simulation to get the properties of the wind on the surface church. 
Table 1: Air velocity and air pressure in the air channel for each variants

\begin{tabular}{|l|c|c|c|}
\hline Simulated variants & Dimensions & Air velocity & Air pressure \\
\hline & {$[\mathrm{mm}]$} & {$[\mathrm{m} / \mathrm{s}]$} & {$[\mathrm{Pa}]$} \\
\hline Variant 1 & $400 \times 400$ & 0.16551 & 0.01719 \\
\hline Variant 2 & $400 \times 450$ & 0.15990 & 0.01470 \\
\hline Variant 3 & $400 \times 500$ & 0.14958 & 0.01343 \\
\hline Variant 4 & $400 \times 550$ & 0.13990 & 0.01239 \\
\hline Variant 5 & $400 \times 600$ & 0.13008 & 0.01153 \\
\hline Variant 6 & $\mathbf{4 5 0}$ x 400 & $\mathbf{0 . 1 6 5 6 8}$ & $\mathbf{0 . 0 1 4 7 5}$ \\
\hline Variant 7 & $450 \times 450$ & 0.15365 & 0.01340 \\
\hline Variant 8 & $450 \times 500$ & 0.14253 & 0.01219 \\
\hline Variant 9 & $450 \times 550$ & 0.13280 & 0.01115 \\
\hline Variant 10 & $450 \times 600$ & 0.12529 & 0.01041 \\
\hline Variant 11 & $500 \times 400$ & 0.16319 & 0.01351 \\
\hline Variant 12 & $500 \times 450$ & 0.14922 & 0.01215 \\
\hline Variant 13 & $500 \times 500$ & 0.13762 & 0.01103 \\
\hline Variant 14 & $500 \times 550$ & 0.12830 & 0.01020 \\
\hline Variant 15 & $500 \times 600$ & 0.12141 & 0.00945 \\
\hline
\end{tabular}

\subsection{Numerical model}

The first model was realized with an air flow of $3 \mathrm{~m} \cdot \mathrm{s}^{-1}$, during the summer with air temperatures approximating $25^{\circ} \mathrm{C}$. In the second model we used obtained values of pressure in monitored points (Fig. 5, Fig. 6), what represented the location of the inlets on the wall in the first model [8].

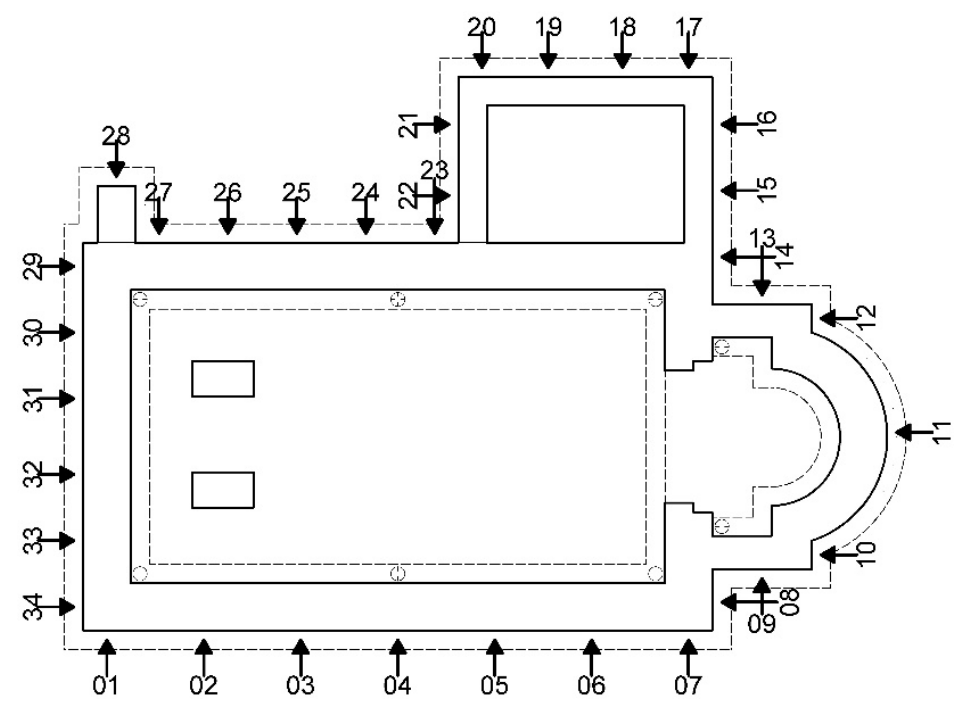

Figure 5: Location of inlets 


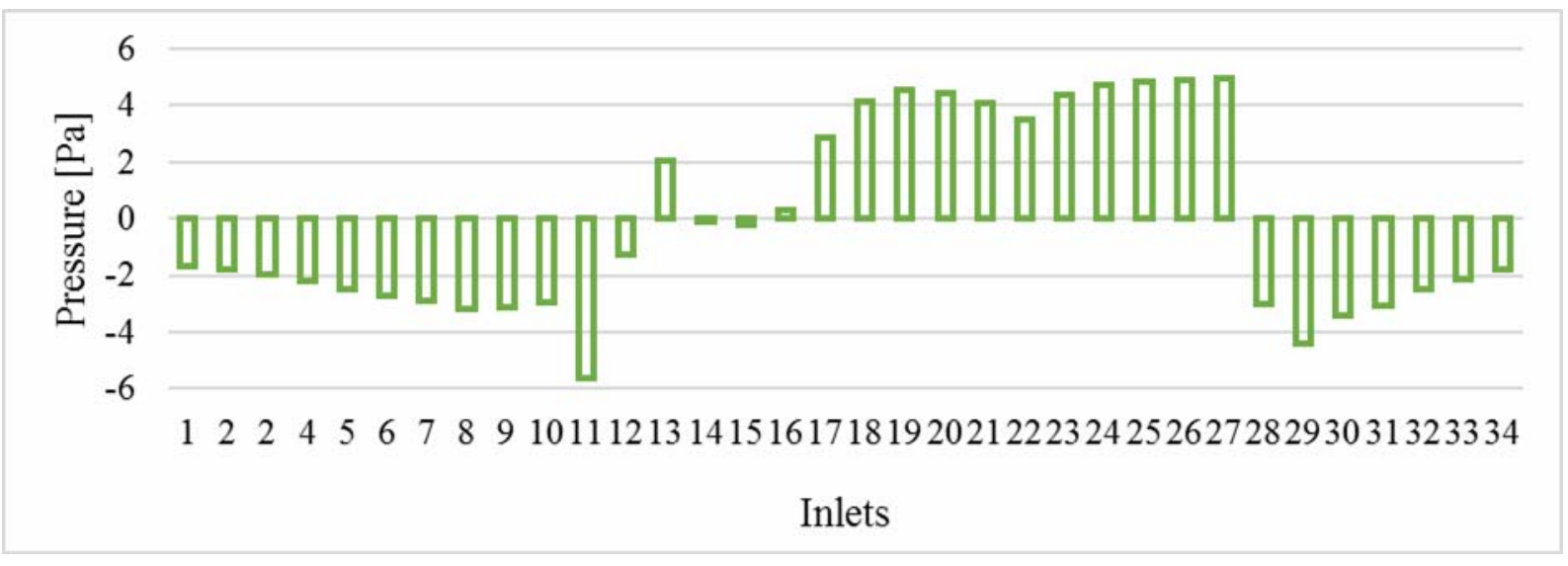

Figure 6: Air pressures in inlets

\section{Results of Numerical Simulation}

In the Figure 7 is displayed dependence of the air velocity on the depth of the air channel. If the depth of the air channel is higher air velocities are lower. Therefore in the final numerical simulation we used lower depth of the air channel with the enlarged width. Final cross-section dimensions of the air channel are $450 \times 400 \mathrm{~mm}$ (Variant 6) $[1,2,3]$.

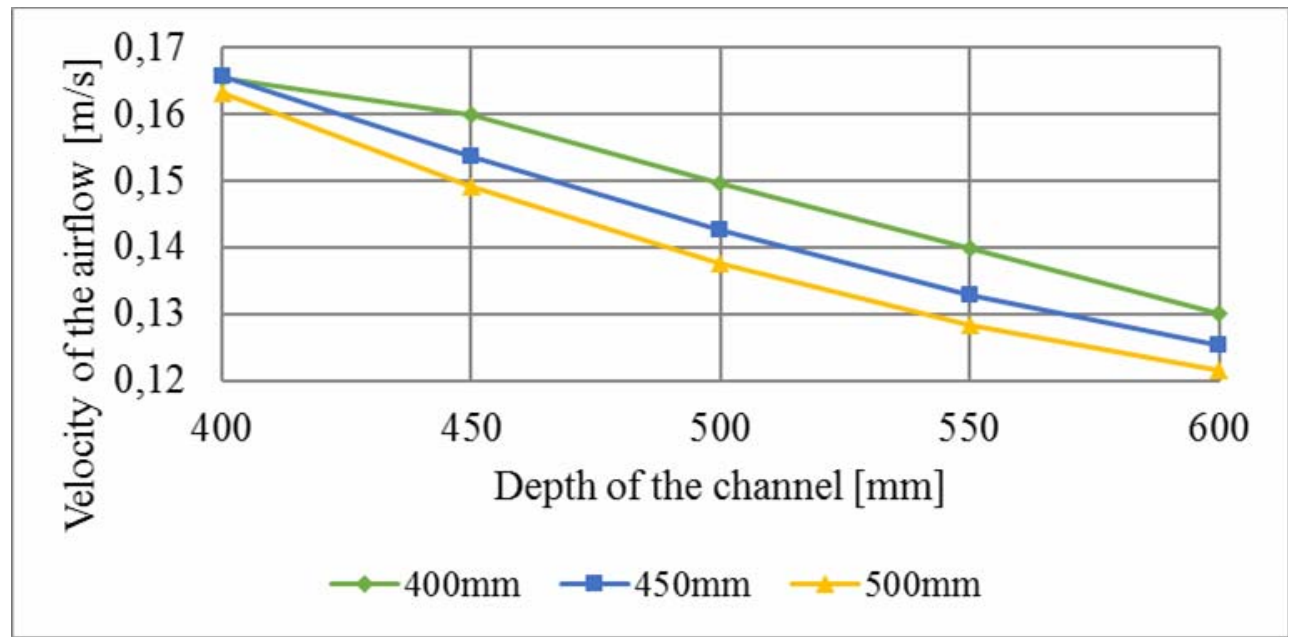

Figure 7: Dependence of the velocity and depth of air channel

The Fig. 8 displayed streamlines air in the air channel around the pillar of church. The streamlines air is colored according to air velocity. In this part of the church is the worst situation, because water content in the masonry is around $9 \%$. The tested samples have been collected from the bottom part of the masonry wall. Results obtained from the numerical simulation in the software ANSYS CFX are satisfactory in the complicated parts of the church as well as at the apse. 


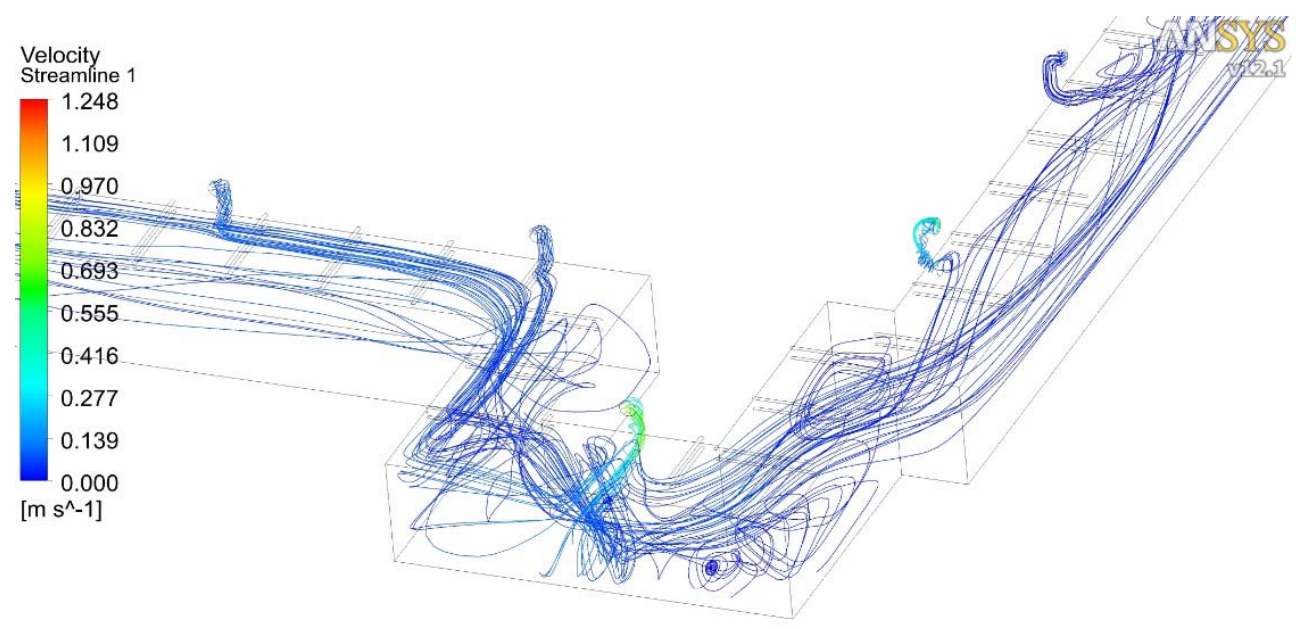

Figure 8: Streamlines air in the air channel around the pillar

The graph in Fig. 9 displayed air velocity in the monitored points 1-118 in the second model. Location of the monitored points is in the centre of the channels in the distance $300 \mathrm{~mm}$.

\section{Conclusion}

The air channel around the church Gemersky Jablonec is simulated in many different variants, see Table 1. Results obtained from the numerical simulation in the software ANSYS CFX showed cross-section $450 \times 400 \mathrm{~mm}$ (Variant 6) as the best for this church. In this case is air velocity in the air channel highest as well as maximal drying effect of the masonry. Final results showed average air velocity in the air channel on the value $0.032 \mathrm{~m} / \mathrm{s}$, more [8].

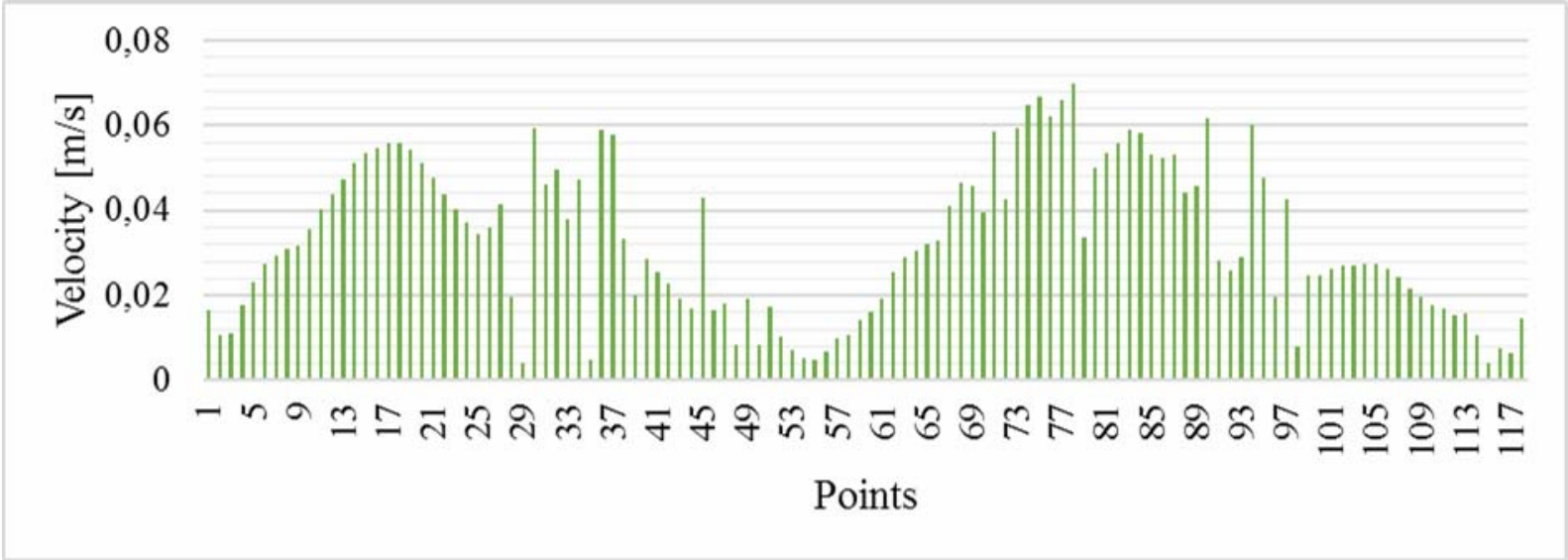

Figure 9: Air velocities in the air channel with the dimensions $450 \times 400 \mathrm{~mm}$ (Variant 6) 


\section{Acknowledgements}

This contribution has been supported by the project "The use of the virtual laboratory for designing energy-efficient buildings" with the project code: 052TUKE-4/2013.

\section{References}

[1] BALÍK Michael et al. (2008). Dehumidification of buildings, Vol. 2.. Praha: Grada.

[2] BALÍK Michael. (2009). Drying of the masonry, Praha: Grada.

[3] FÁRA Pavel. (2007). Examples of remediation basements against moisture. CUBIS, s.r.o., Praha, Construction Yearbook (103-108). Bratislava: Jaga Group.

[4] ¿̌EHÁK Jozef. (1993). Survey of drainage tunnels in the monastery Milevsko. Praha http://old.speleo.cz/soubory/speleo/sp16/milevsko.htm

[5] BURGETOVÁ Eva, MATEJČEK Róbert. (2008). Proposal for remediation of damp masonry church. Giles in Mliesk. Bratislava: ASB, http://old.speleo.cz/soubory/speleo/sp16/milevsko.htm.

[6] HAVEL Miroslav. (2012) Procedure for remediation of damp masonry locks on the upper Vimperk. Bratislava: ASB, http://www.asb.sk/stavebnictvo/rekonstrukcia/postup-sanacievlhkeho-muriva-horneho-zamku-vo-vimperku.

[7] RENČKO Tomáš, SEDLÁKOVÁ Anna. (2013). Assessment of underfloor ventilation of historic buildings using ansys cfx. In Budownictwo o zoptymalizowanym potencjale energetycznym, 2013 (98-106). Krakow.

[8] BRESTOVIČ Tomáš, JASMINSKÁ Natália, KUBÍK Michal. (2013). Development of software support for ANSYS CFX. In 32. stretnutie katedier mechaniky tekutín a termomechaniky Žilina, 25.-28.júna 2013 (5-8). Žilina: Edis. 